AFRICAN

\title{
Denying the Dalai Lama: South Africa's visa diplomacy, human rights and the media
}

\author{
by Suzette van der Westhuizen* \\ Government Communication and Information System, South Africa \\ Jo-Ansie van Wyk \\ Department of Political Sciences \\ University of South Africa, South Africa
}

\begin{abstract}
South Africa has declared human rights a cornerstone of its foreign policy. However, its denial of visas to the Dalai Lama to visit South Africa on three successive occasions is illustrative of the contradictions in the country's human rights foreign policy. South Africa's decision to promote Sino-South African relations rather than address the causes of the Dalai Lama's exile, and China's occupation of Tibet and poor human rights record has resulted in widespread media reaction in South Africa and abroad. Three related matters were highlighted, namely South Africa's human rights foreign policy; the country's visa diplomacy and its refusal of visas to the Dalai Lama to promote Sino-South African bilateral trade and diplomatic relations; and the media as a key domestic foreign policy actor. This study uses a constructivist approach. It concludes that the South African media framed and constructed the South African government's public and visa diplomacy in respect of the Dalai Lama from the ideational turn (the promotion of human rights) whereas South Africa's foreign policy is presented as replaced by a hegemonic turn in favour of China.

*Writing in her personal capacity and does not reflect the views of the South African government
\end{abstract}


AFRICAN

EAST-ASIAN

AFFAIRS

\section{Introduction}

China's power, status and prestige, as well as its ideological and solidarity links with South Africa makes it a very attractive diplomatic partner. In fact, these bilateral relations have moved beyond mere routine diplomacy to a strategic partnership. Yet, Pretoria's kowtowing and evident adaptation and conformity to Beijing is unique in its diplomatic relations. In constructivist terms, identity-related reasons legitimation, conformity and esteem (Finnemore and Sikkink, 1998: 887-917) - offer some explanations for Pretoria's diplomatic behaviour in this instance. Having opted for China, rather than Taiwan, as a diplomatic partner, and realising the economic and political benefits, South Africa may have sought to gain the approval and acceptance of China; thus attempting to be part of its "in-group" in the international community and realising its diplomatic ambitions. Moreover, enjoying the status and prestige of the so-called South African miracle, South Africa may have attempted to maintain the status and prestige associated with this; thus maintaining its esteem. By opting to select the actor with the most material capabilities to offer, South Africa undermined, and perhaps reversed, the "ideational turn" (Finnemore and Sikkink, 1998: 888) in its foreign policy, namely a normative construction, or idea (human rights) it so dearly participated in and benefitted from. South Africa's institutionalisation of its relations with China, whilst not attempting to establish this in the case of Tibet, also underscores, inter alia, South Africa's subjugation to China as a hegemonic power. This view emanating from and supported by the media surveyed for this study, and perhaps a hegemonic turn (cf. Cox, 1981: 126-155) in the country's foreign policy, is further illustrated in its preference for big power alliances with regional and global hegemons in BRICS and the India-Brazil-South Africa Dialogue Forum (IBSA).

Post-apartheid South Africa's relations with the People's Republic of China (hereafter China) (Alden and $\mathrm{Wu}, 2014$; April and Shelton, 2014), and its foreign policy and principles are well documented (see, for example, Landsberg, 2010). One of these principles is the country's advocacy of and commitment to human rights. However, this area has proved to be one of the contradictory and controversial aspects of South Africa's post-1994 foreign policy and diplomacy (Titus, 2009). This 


\section{AFRICAN \\ EAST-ASIAN \\ AFFAIRS

is, amongst others, clearly illustrated in the country's denial of visas to the current Dalai Lama, which elicited widespread media reaction; a situation which also illustrates the under-researched link between foreign policy, public diplomacy and the media in South Africa.

A global public figure and symbol of human rights and a Nobel Laureate, the current Dalai Lama, believed to be the $14^{\text {th }}$ reincarnation of the Buddha Avalokiteshvara, is the Head of State and the spiritual leader of Tibet. As a 16-year-old, he was forced to assume full political power during a crisis precipitated by the Chinese Communist invasion and occupation of Tibet in 1959. Despite Tibetans' rebellion in reaction to the invasion, China suppressed the uprising, and the Dalai Lama fled to neighbouring India where he established a democratic government-in-exile working for the freedom of Tibet and the welfare of Tibetan refugees. In 1963, the Dalai Lama promulgated a constitution for a democratic Tibet which Tibetans regard as an independent state under illegal Chinese occupation, and maintain that neither China's military invasion nor the continuing occupation by the People's Liberation Army had transferred the sovereignty of Tibet to China (Tenzin, 1996).

Since 1959, the Dalai Lama has actively campaigned internationally for the Tibetan cause (Tenzin, Undated). Since his first visit to the West in 1973, he has met many world leaders, members of European royalty and civic and religious leaders. The Dalai Lama has also, amongst others, addressed the United States (US) Congress, the European Parliament and innumerable university, inter-faith and civic gatherings (Tibet Society, 2013).

The Dalai Lama also campaigned for the end of apartheid in South Africa and, since 1994, visited the country on three occasions in 1996, 1999 and 2004. In 1996, President Mandela, despite perceived pressure from China granted a visa to and met with the Dalai Lama (Saks, 2011). Mandela's decision coincided with the time South Africa indicated that it would decide whether to end relations with the Republic of China (Taiwan) in favour of China. Subsequently, South Africa opted for a "Two China" policy, which, due to perceived Chinese pressure, was later changed to favour China only. 
AFFAIRS

While allowing the Dalai Lama to visit South Africa in 1999 and 2004, President Mandela's successor, President Thabo Mbeki did not agree to a one-on-one meeting with the Dalai Lama during his 1999 visit to South Africa; signalling a shift in South Africa's visa diplomacy, a shift in the discourse on the Dalai Lama in the South African government, as well as the country's human rights foreign policy. In 1999, South Africa issued a visa to the Dalai Lama to attend the Parliament of the World's Religions (PWR) in Cape Town. At the time, President Mbeki's aide, Parks Makahlana, argued that the Dalai Lama was only one of a host of religious leaders who wanted to meet President Mbeki, and that the PWR organisers had agreed that a representative group, including the Dalai Lama, rather than individuals, would meet the President (iol, 2 December 1999). This pattern was repeated when the Dalai Lama could not meet President Thabo Mbeki on his second visit to South Africa in 2004, and set the scene for future denial of visas to the Dalai Lama on three subsequent occasions (2009, 2011 and 2013; hereafter referred to as the Dalai Lama Affair).

Global and local questions were raised about the motivation for South Africa's volte face resulting in wide local and international media reaction and coverage. Moreover, South Africa's stated human rights foreign policy was questioned, as well as the possible influence of China in respect of South Africa's refusal to grant a visa.

Against the aforesaid, this article addresses three neglected areas of South Africa's foreign policy, namely the country's visa diplomacy; its refusal of visas to the Dalai Lama as a human rights issue; and the media as a domestic foreign policy actor. South Africa is no stranger to visa diplomacy; having been on the receiving end during apartheid due to international sanctions and embargoes prior to 1994. Since 1994 South Africa has seen the declaration of a number of individuals as personae non grata and denying visas to others (Mail \& Guardian, 26 March 2014). The aim is also to investigate the South African media as a domestic source of foreign policy, and how it constructed South Africa's foreign policy decision in respect of the Dalai Lama's intended visits; and the government's constructions in response to each denial. In order to achieve the objectives of the study, a constructivist approach is employed. It is thus assumed that international reality is cognitively and socially 


\section{AFRICAN \\ EAST-ASIAN \\ AFFAIRS

constructed to provide meaning to the material world, and that international politics is constructed by influential ideas, collective values, culture and social identities (Adler, 1997: 319). In the Dalai Lama Affair, identities, interests and norms values were repeatedly highlighted by the South African government.

It is impossible to focus on all media coverage in the Dalai Lama saga. Therefore, the media set used for this study consisted predominantly of, but not limited to, the mainly the Gauteng-based publications of largest South African media group, Independent News \& Media (hereafter Independent Media) on the basis of Kariithi's (2010) "reducing rectangles". The latter assumes that of everything taking place at a given moment, only a certain portion is noticed. Of all that is noticed, only a certain segment is recorded by the media. Of all that is recorded, only a certain fraction can be monitored. Of what is monitored, only a certain share can be analysed. Independent Media publishes, amongst others, The Star, Saturday Star, Pretoria News, Pretoria News Weekend, Cape Argus, Weekend Argus, The Mercury, Daily News, The Independent, The Sunday Independent, and Independent Online (iol) (Independent Media, 2015). By June 2015, Independent Media's shareholders included Sekunjalo Media Consortium (the majority shareholder); the Government Employees Pension Fund (GEPF) managed through the state-owned Public Investment Corporation (PIC); and Interacom Investment Holding Limited (China International Television Corporation [CITVC]) and China-Africa Development Fund (CADFUND) (Independent Media 2015).

As the Gauteng-published media are in the government's immediate environment, the South African government, therefore, pays most attention to these sources in considering its reaction to media reporting. For this research, news reports, feature articles, and editorials were included in the media set. The article is structured to analyse South Africa's post-apartheid human rights foreign policy and public diplomacy, the conditions surrounding the three visa denials to the Dalai Lama, the implications of these denials, and the South African government's construction of its justification of its decisions in each instance. 


\section{South Africa's post-apartheid foreign policy and public diplomacy}

Writing about South Africa's post-apartheid foreign policy on the eve of South Africa's first democratic elections, Nelson Mandela (1993) stated that the settled norm of human rights would be "the light that guides South Africa's foreign policy". This set the tone for South Africa's foreign policy in the aftermath of apartheid, with the incumbent African National Congress (ANC) government declaring the promotion of human rights as a foreign policy priority.

Despite this lofty ideal and repeated foreign policy mantra, South Africa's human rights foreign policy was repeatedly questioned stemming from, for example, its position on reported human rights abuses by the governments of, for instance, China and Zimbabwe; its human rights-related voting record as a non-permanent member of the United Nations Security Council (UNSC) from 2007 to 2008 and again from 2011 to 2012 and the United Nations Human Rights Council (UNHRC); as well as its decisions to decline visas to the $14^{\text {th }}$ Dalai Lama (SAIIA, 2009). Despite these questions, the South African Minister of Foreign Affairs, Nkosazana Dlamini-Zuma, confirmed that there had been "no change in the fundamental underpinnings of our [South Africa's] foreign policy since the advent of our democracy in 1994" and that "our stand on human rights is still the same" (DFA, 2007). Apart from embracing a normative dimension of South Africa's foreign policy, the country also embraces public diplomacy as a practical dimension of its foreign policy as a particular type and practice of diplomacy (Melissen, 2011). The media is therefore recognised as one of the instruments in a state's conduct of public diplomacy; referred to as the "centralised mass-media approach" to public diplomacy whereby governments need to correct daily perceived constructions or misrepresentations of their policies and attempt to convey a longer-term strategic message (Nye, 2010). The main strength of the mass-media approach is its audience reach, ability to generate public awareness, and to set the policy and political agenda (Nye, 2010). There is thus a link between foreign policy, public diplomacy and media liaison. How a government goes about conducting these relations with the media can result in either good or tense government-media relations. In fact, the South African government has 


\section{AFRICAN \\ EAST-ASIAN \\ AFFAIRS

institutionalised this by establishing the Public Diplomacy Branch to communicate South Africa's role and position in international relations in the domestic and international arenas to provide national and international direction to the state's public diplomacy.

\section{Constructing denial and media response}

As indicated, South Africa, on three occasions, denied issuing a visa to the Dalai Lama; resulting in critical media coverage of these decisions. These occasions included the denials of visas to the Dalai Lama to attend a peace conference linked to South Africa's hosting of the 2010 Fédération Internationale de Football Association (FIFA) World Cup scheduled to be held in Johannesburg in March 2009; to attend the $80^{\text {th }}$ birthday celebrations of Archbishop Emeritus Desmond Tutu, a fellow Nobel Laureate, in Cape Town in 2011; and a planned summit of Nobel Peace Laureates in Cape Town in honour of Nelson Mandela in 2014 who passed away in 2013. This section contextualises these denials.

\section{The 2009 denial}

In December 2007, Thabo Mbeki lost the ANC Presidency and was replaced by Jacob Zuma. By September 2008, Mbeki's party removed him as the South African President and replaced him with Kgalema Motlanthe, paving the way for Jacob Zuma's presidency in the wake of South Africa's national elections in early 2009. In the build-up to South Africa's hosting of the 2010 FIFA World Cup, a particularly politically tense period in South Africa, the country's three African fellow Nobel Laureates - Presidents Nelson Mandela and FW de Klerk, and Archbishop Emeritus Desmond Tutu, using a letter of President Kgalema Motlanthe, Mbeki's successor invited the Dalai Lama to participate in a peace conference in March 2009 linked to the 2010 FIFA World Cup (Pretoria News Weekend, 21 March 2009; iol, 24 March 2009; Sunday Independent, 29 March 2009).

The South African government's initial stance in 2009 was that no invitation had been extended to the Dalai Lama, followed by a response from the then South African Department of Foreign Affairs (DFA) denying that the government was 
AFFAIRS

blocking the visit as no invitation had been extended to the Dalai Lama (iol, 22 March 2009). Denials that South Africa had been pressured by the Chinese government followed. The ruling party referred to this in its defence of government's decision, whereas the DFA stated that the Dalai Lama was welcome to visit South Africa, but "not now" (Sunday Independent, 29 March 2009). In fact, the Chinese embassy in Pretoria admitted to appealing to the South African government not to allow the Dalai Lama into South Africa, warning that it would harm Sino-South African relations (Pretoria News Weekend, 21 March 2009). The Chinese embassy also explained that it was a particularly inopportune time for the Dalai Lama to visit South Africa as it was the $60^{\text {th }}$ anniversary of what Tibetans regarded as China's military invasion and occupation of Tibet, but which the Chinese government described as its liberation of Tibetans from "feudal serfdom" (Pretoria News Weekend, 21 March 2009).

As the media and conference organisers maintained that the Dalai Lama was invited to speak at the peace conference linked to the 2010 FIFA World Cup, the South African government finally admitted that it had denied the Dalai Lama a visa to attend the conference, saying it was not in South Africa's interest for him to attend as it did not want to "divert attention" from hosting the 2010 FIFA World Cup (Pretoria News Weekend, 21 March 2009; Pretoria News, 24 March 2009). Media like Weekend Argus (22/3/2009) made it clear that they considered the fact that South Africa had closed its doors to the Dalai Lama "a disgrace", who, the world over, commanded immense respect. The government conceded that it was also faced with the choice between allowing the Dalai Lama access and damaging relations with China (iol, 22 March 2009; The Star, 24 March 2009). The government maintained that it did not want the peace conference to be used as a platform to advance political causes (Sowetan Live, 26 March 2009). Though government denied the suggestion, the media interpreted this as bowing to pressure from China (Sowetan Live, 26 March 2009). Another dimension emerged when the South African government finally indicated that they did not want to jeopardise relations with China (The Mercury, 24 March 2009). The South African government explained that its decision was made not to jeopardise bilateral relations with China 


\section{AFRICAN \\ EAST-ASIAN \\ AFFAIRS

(The Mercury, 24 March 2009). South Africa also insisted that it was not in the country's interest to invite the Dalai Lama and rejected accusations that South Africa had denied the Dalai Lama entry under pressure from China (Pretoria News, 23 March 2009). It is clear that the government was repeatedly pushed to adapt its stated public policy messages with regard to this story. Subsequently, the media reported that the South African government justified its decision by saying "it did not want to endanger the government's relationship with China" (The Independent, 23 March 2009).

The South African media further reacted by describing the government's refusal as a "disgrace"; referring to South Africa's "spinelessness on the international stage" as "embarrassing" (Weekend Argus, 22 March 2009). It also argued that the world, like South Africans, had become accustomed to the South African government's "extraordinary hypocrisy" in foreign relations as politicians paid lip-service to principles; yet thoughtless pragmatism governed foreign policy (Weekend Argus, 22 March 2009). Regarding the argument that the Dalai Lama's visit would divert attention from the focus of the 2009 peace conference, the media suggested that government officials would have realised that the snub they were defending was creating more publicity than allowing the Dalai Lama to attend the conference (Daily News, 24 March 2009). There were also media suggestions that there would soon be proof enough that the ANC decided to ban the Dalai Lama because of all the Chinese money that went into the party's coffers. The media further argued that, increasingly, the world could be divided into those countries that were succumbing to pressure from China, and those that were not; with South Africa falling into the former category.

The media further referred to the "one-China policy" that meant accepting that Taiwan was a renegade province of China that had to return to the mother country (Pretoria News, 30 March 2009). China's apparent mounting sensitivity about the Dalai Lama implied that the policy had been secretly extended to Tibet. It was noted that China proffered that part of the respect they accorded to Africa was not to impose conditions on their aid, as Western nations did. The paradox was that by enforcing this "no-meet-the-Dalai Lama policy" at the risk of losing aid, Beijing was 
AFFAIRS

being far more conditional than any Western nation would dare to be.

In the wake of the 2009 denial, President Zuma's newly-appointed Minister of International Relations and Cooperation, Maite Nkoana-Mashabane, reiterated that the country's human rights foreign policy would remain unchanged, while emphasising that the Dalai Lama was now free to visit the country, stating "though we did not communicate clearly at first what had transpired, this country discriminates against no one, and the Dalai Lama is more than free (to visit)" (The Star, 15 May 2009).

\section{The 2011 denial}

At the end of August 2011, the media reported that "another row" in respect of the Dalai Lama might be brewing due to the invitation by Archbishop Emeritus Desmond Tutu to the Dalai Lama to attend Tutu's $80^{\text {th }}$ birthday (Sunday Independent, 28 August 2011). As the prospect of another visit to South Africa by the Dalai Lama came up in 2011, the media, and later the representative of the Dalai Lama in South Africa quoted statements from 2009 not ruling out future visits and challenged the government to grant the visa, referring to the 2009 undertaking by the South African government that the Dalai Lama would be free to visit South Africa in future (Daily News, 13 October 2011; iol, 28 August 2011). The media also referred to the 2009 explanation that the real problem then was that visit would have coincided with the $50^{\text {th }}$ anniversary of the Dalai Lama fleeing into exile in India and challenged President Zuma to grant the visa. In not granting the visa in 2011, South Africa clearly backtracked on these stated positions (The Mercury, 26 March 2009).

Following this, South Africa's Department of Home Affairs (which administers admissions into the country and, therefore, issues visas) announced that the Dalai Lama had not applied for a visa, whereas Minister Nkoana-Mashabane admitted to receiving the application; saying it was processed (The Star, 7 October 2011; iol, 28 August 2011). The South African government failed to provide answers about the status of the visa application. It was also pointed out that a decision on the Dalai Lama's visa application would not be made public as it would be communicated to the applicant (iol, 2 October 2011). Due to subsequent delays, the Dalai Lama finally 


\section{AFRICAN \\ EAST-ASIAN \\ AFFAIRS

cancelled his application (The Star, 5 October 2011). Kgalema Motlanthe, by now appointed as Jacob Zuma's Deputy President, responded that the South African government would have issued a visa had the Dalai Lama not cancelled his application (The Star, 5 October 2011). As the Deputy President was challenged to issue such a visa, his spokesperson merely stated that the Deputy President did not issue visas.

Like the 2009 denial, the media was harsh in its criticism of the South African government's handling of the 2011 invitation to the Dalai Lama. The Department of International Relations and Cooperation (DIRCO) Draft White Paper on Foreign Policy, which embraced the concept of ubuntu, published in 2011 was quoted, concluding that South Africa had not chosen to affirm the humanity of the Tibetan people, presumably because Tibet had nothing to offer South Africa (Pretoria News, 6 October 2011).

The media also argued that China would not stop investing or trading with South Africa if the government allowed the Dalai Lama to visit the country and suggested that cash might have been secured for the ANC, which could be cut off without affecting the Chinese economy (Pretoria News, 6 October 2011). Moreover, the media commented that it seemed that all pretence at finding a balance between practical and principled considerations in South African foreign policy had been abandoned (Cape Times, 5 October 2011).

Moreover, the media described South Africa's approach as "unaccountable, secretive and disrespectful"; accusing the South African government of pursuing a "cynical strategy" over the planned visit by the Dalai Lama by delaying to grant a visa so that the Dalai Lama had to cancel his visit (Cape Times, 5 October 2011). In response, the South African government claimed it never came under any pressure from China to prevent the Dalai Lama from visiting and would have given the Dalai Lama a visa had he not cancelled. This explanation was seen as "implausible".

The South African government sought to look unhurried and strong in considering the Tibetan spiritual leader's application for a visa. Instead, it showed weakness and an inability to deal with tricky situations. An explanation by the President saying no 
AFFAIRS

one in government was saying why he did not get a visa, because it was a "state secret", was seen as foreboding the Dalai Lama visa affair as an indication of how the Protection of State information Bill (PSIB) would operate once it came into effect. However, in 2011, two opposition Members of Parliament (MPs) and struggle stalwarts, Mangosuthu Buthelezi and Mosiuoa Lekota, took government to court over its handling of the Dalai Lama's visa application. In Buthelezi \& Another $v$ Minister of Home Affairs \& Others (2012), Judge Nugent of the Supreme Court of Appeal ruled in his judgement that the Department of Home Affairs and the other respondents in the case "unreasonably delayed" the decision "whether to grant or withhold the visas relevant to this case and in so doing acted unlawfully".

\section{The 2014 denial}

In 2014, the South African government responded similarly to the 2011 visa application. The Dalai Lama applied for a visa to attend a World Summit of Nobel Peace Laureates in Cape Town meant to commemorate the $20^{\text {th }}$ anniversary of the end of apartheid and the legacy of former President Nelson Mandela (The Herald, 2 October 2014). The City of Cape Town had budgeted ZAR 10 million for the summit's 1,500 guests, including fellow Nobel Peace Prize laureates, invited to attend (The Herald, 2 October 2014). However, a representative of the Dalai Lama, Nangsa Choedon, was quoted saying the South African government had requested that the Dalai Lama withdraw his application for a visa as South Africa was not able to grant the visa as it would "disturb" Sino-South African relations (Business Day Live, 2 September 2014). South African government spokespeople denied this, saying the application was still under review and "a closed matter" (News24, 4 October 2014). This led to further media accusations against the South African government of not having "the guts to stand in public and defend its decisions, choosing instead to remain silent" (Times Live, 3 October 2014). Subsequently, the Dalai Lama's South African office revealed that the spiritual leader would cancel his visit because it would not be granted in deference to South Africa's relations with China (Times Live, 30 September 2014). DIRCO had received written confirmation from the Dalai Lama's office indicating that he had cancelled his planned visit to South Africa, resulting in an outrage from the media (iol, 4 September 2014). Many 


\section{AFRICAN \\ EAST-ASIAN \\ AFFAIRS

repeated. The South African media rejected DIRCO's claim that the Dalai Lama voluntarily cancelled his application for the visa before it could be processed as "nonsense" (The Citizen, 1 October 2014). The official opposition party, Democratic Alliance (DA), further challenged President Zuma and his government to go on record and "categorically" confirm that South Africa would have issued a visa to the Dalai Lama had he not cancelled his application (Pretoria News, 6 October 2014). Clayson Monyela, DIRCO Deputy Director-General of Public Diplomacy, responded by indicating it was not "proper" to answer "hypothetical" questions on whether South Africa would have approved the visa application, or not. It was remarked that South Africa was losing its hard-fought reputation as a champion of human rights and its independence (The Star, 3 October 2014). The decision was also seen as evidence of "cynical national interests" triumphing over the government's professed idealism (The Witness, 3 October 2014). The media also accused the South African government of not having "the guts to stand in public and defend its decisions, choosing instead to remain silent" (Times Live, 3 October 2014). The media further argued that the decision, or "indecision", exposed South Africa's falsehood of BRICS (the Brazil-Russia-India-China-South Africa grouping) being an organisation of equals (Pretoria News, 6 October 2014).

Cape Town Mayor Patricia de Lille, a member of the DA, and host to the said conference, confirmed that the decision to move the event to another city would cost the city ZAR 60 million in lost economic opportunities, tourism and job creation (Cape Argus, 3 February 2014). She said the primary reason for the relocation was the fact that the South African government refused to issue a visa to the Dalai Lama. She explained that she had contacted The [South African] Presidency in March 2014 about the prospect of hosting the summit, only to get a response at the end of August 2014. A group of 14 Nobel Laureates had also appealed to President Jacob Zuma to grant the Dalai Lama a visa, with no acknowledgement. Seemingly, the South African government had treated these requests with disdain and showed they were more intent on pleasing Beijing than ensuring that a prestigious international event was held in South Africa. They had undermined South Africa's international standing and embarrassed the country, suggesting that South Africa was being "sold 
AFFAIRS

to the highest bidder" - China (Cape Argus, 3 February 2014).

In response, presidential spokesperson Mac Maharaj said The Presidency took "strong exception" to De Lille's comments (The Citizen, 4 October 2014). Maharaj claimed government had not denied the Dalai Lama a visa because he had effectively cancelled his own application by indicating he would not be attending the summit; reiterating a similar claim by DIRCO. Spokesperson for Parliament's Portfolio Committee on International Relations and Cooperation Siphosezwe Masango said perceptions of trying to appease China were unfounded. Trade with the Far East and any other strategic trading partners did not, and should not mean China's adversaries were South Africa's (Mail \& Guardian, 3 October 2014).

Against the aforesaid, it can be deduced that, as South Africa's relations with China consolidated, its rejection of the Dalai Lama escalated. In 2009, the South African government was keen to interact with the media in an attempt to put defendable arguments in the communication environment. However, its approach to media reaction in 2011 was very different to its approach in 2009 in that the government increasingly attempted to evade, rather than to engage, with the media about the issue. The avoidance and denial tactics did little to arrest the fury expressed in the media about the way the government handled the 2014 application. Very little was learned from previous experiences and the government chose to go the same route with the 2014 application, with more or less the same result. The government merely followed the 2011 approach in getting the Dalai Lama to cancel his visit to South Africa. It then created the impression that the application was still under review when the trip was called off. Harsh media criticism and public outcries resulted in both instances from the government's apparent reluctance to handle the matter through public diplomacy platforms; due to, inter alia, political pressure from China, lacking a convincing communications strategy and ineffective government communication.

\section{Implications of visa denials}

The Dalai Lama Affair has had several implications for South Africa's human rights foreign policy; formulations of South Africa's national interests; the country's public 


\section{AFRICAN \\ EAST-ASIAN \\ AFFAIRS

and visa diplomacy; and the role of the media.

\section{South Africa's human rights foreign policy}

With its emphasis on human rights, South Africa has managed to uphold a rhetorical advantage in its post-1994 foreign policy. However, the Dalai Lama Affair illustrated the selective application (and thus discriminatory nature) of South Africa's human rights policy. As a result, a strong and critical media voice emerged accusing the South African government of abandoning human rights principles under pressure from China for the sake of beneficial trade relations.

In response, the South African government maintained that abiding to the spirit of the South African Constitution (Act 108 of 1996) and a commitment to international human rights was less in South Africa's interests than kowtowing to China (Weekend Argus, 2 March 2009). Analysts explained that there was not necessarily a conflict between the pursuit of values and national interests; rather, values were often intangible forms of national interests (The Mercury, 29 March 2010). The South African Constitution (Act 108 of 1996) enjoined the government to pursue a balanced foreign policy, both value-based and interest-driven. However, a lack of consensus on what constituted the national interests bedeviled this balance. Despite the very strong media attack on South Africa's foreign policy and human rights credentials, the South African government did very little to defend itself in this respect, but chose to make it a national interest issue. In its response, the ANC, the governing party, merely maintained that this decision did not compromise South Africa's stand on human rights. The South African government's silence on China's human rights record is in stark contrast to, for example, South Africa's diplomacy of anger vis-a-vis Israel's human rights policy in respect of Palestinians (see Hall, 2011: 521-555). As far back as 2000, South African human rights groups and opposition parties urged President Thabo Mbeki to use the opportunity of a visit to South Africa by then Chinese President Jiang Zemin to emphasise South Africa's commitment to civil liberties. However, comments by Chinese Foreign Ministry spokesperson Zhu Bangzao suggest that human rights did not come under discussion (BBC, 2000). 
The human rights issue relating to the Dalai Lama resurfaced in 2011. In response, Archbishop Tutu's harsh words to the South Africa government, saying it was "disgraceful" and "worse than the apartheid government", was not sensitive to the sentiments of the Constitution (The Star, 5 October 2011). The media argued that the way the government handled the matter suggested a lack of moral fibre and ineptness in the foreign policy arena (Cape Times, 5 October 2011). Analysts such as Adv. Shami Kholong, a policy and risk analyst, concurred that the government's "abortion" of the Dalai Lama's visit undermined a pillar of the South African Constitution, i.e. the protection of human rights (The Star, 6 October 2011). Again, the government did not defend itself against accusations on the issue of human rights, especially as it did not take a decision to refuse a visa. In 2014 communication from the South African government merely addressed the bureaucratic circumstances around the Dalai Lama's 2014 application. DIRCO commented that anybody that tried to "push the narrative" that the Dalai Lama had been denied entry into South Africa or denied a visa was "factually incorrect" (SABC, 3 October 2014). The Dalai Lama had sent a written confirmation that he had now decided to cancel his plans to visit South Africa - he had effectively withdrawn his application (SABC, 3 October 2014).

\section{National interests and the Dalai Lama Effect}

In an effort to ease pressure on it, the South African government explained that its intention to advance the country's national interests justifies its decision to deny visas to the Dalai Lama. The media framed this justification as "bowing to pressure" from China (Mail \& Guardian, 28 September 2011). The South African government retorted that it did not jeopardise bilateral relations with China. The government further explained that it was not in South Africa's interest to invite the Dalai Lama, but rejected suggestions that it had denied him entry under pressure from China (Pretoria News, 23 March 2009). The media also linked the decision to China's establishment of an office in Johannesburg to disburse a ZAR 50 billion ChinaAfrica Development Fund (CAD Fund) (Pretoria News, 23 March 2009). Independent Newspapers Foreign Editor, Peter Fabricius, noted that China was demanding much more from African states in enforcing its "no-meet-the-Dalai Lama 


\section{AFRICAN \\ EAST-ASIAN \\ AFFAIRS

policy" than any Western nation would dare to (Pretoria News, 30 March 2009). This is indicative of the so-called Dalai Lama Effect, which refers to China's influence over states hosting or planning to host the Dalai Lama (Fuchs and Klann, 2011). The Chinese administration threatens, in a more-or-less open manner, that meetings between its trading partners' officials and the Dalai Lama will be met with animosity and lead to subsequent deterioration in their trade relationships. Research has shown that China has rewarded states denying visas to the Dalai Lama and has instituted punitive measures against states hosting and supporting the Dalai Lama (Fuchs and Klann 2011). This is also evident in Sino-South African relations since 2009 (the first denial of a visa to the denial); a period which coincides with Jacob Zuma's presidency. In fact, Alden and Wu (2014: 15) concluded that "two-way trade has flourished under the Zuma administration", with China becoming South Africa's largest trading partner during this period.

As the South African government admitted in 2009 it had refused the Dalai Lama a visa to attend the peace conference, it also explained that it was "not in South Africa's interest" for the Dalai Lama to attend as the media focus would shift away from the 2010 FIFA World Cup (The Star, 24 March 2009). The media also suggested that the decision not to grant a visa to the Dalai Lama had more to do with what decision-makers perceived to be "the best [i.e. South Africa's economic] interests" of the country, than distraction from the World Cup event (Daily News, 24 March 2009).

Analysts argued that South Africa's indecision, incompetently tossing the application from one official to the other, was informed by a desire to please "new colonial master" China (The Star, 6 October 2011). Like 2009, and despite protestation from the South African government, the media consensus was that the government gave in to pressure from China in not granting a visa to the Dalai Lama. It is noteworthy from the coverage in the media set monitored that whereas the government did not do much to contest the human rights angle to the story, it did, however, challenge the accusation that it took the decision under pressure from China. 
AFFAIRS

\section{Visa diplomacy}

South Africa's denial of visas to the Dalai Lama is also an indication of the significance of a state's immigration requirements as an element of its sovereignty and territorial control. In 2014, South Africa ranked $42^{\text {nd }}$ in the Henley Visa Restrictions Index, produced in cooperation with the International Air Transport Association (IATA); placing South Africa behind Seychelles $\left(28^{\text {th }}\right)$ and Mauritius $\left(30^{\text {th }}\right)$ as the most accessible African states with visa-free arrangements with 94 states (Henley \& Partners, 2014: 2). The 2014 position represents a decrease in the accessibility of South Africa as; in 2008 the country was ranked $35^{\text {th }} ; 47^{\text {th }}$ in 2010 , and 50 $0^{\text {th }}$ in 2012 (Henley \& Partners 2014: 6). Moreover, the Dalai Lama Affair is a clear example of the country's visa diplomacy; i.e. the issuance or denial of a visa to enter a country in order to express a particular diplomatic position and to influence another actor (Stringer, 2004: 2). Defined as a "tangible measure used to communicate a government's diplomatic mood", visa diplomacy is, therefore, a particular instrument of a state's foreign policy used to coerce or consent; restrict or enable global mobility (Stringer, 2004: 6). The Dalai Lama Affair can have further significant diplomatic implications for South Africa. In this instance, South Africa has denied entry of a Head of State; albeit in exile. However, in contrast it has hosted Heads of State such as Robert Mugabe (Zimbabwe) and Omar al-Bashir (Sudan) with questionable human rights records; in some instances indicted by the International Criminal Court (ICC).

\section{Possible explanations for South Africa's visa denial}

A media statement by the Chinese embassy in Pretoria seems to imply that the Chinese government had appealed to the South African government not to issue such a visa in 2009. The South African government seemed to want to refute such an interaction. Asked if South Africa had consulted China before taking the decision not to grant a visa to the Dalai Lama, the South African government said it was a decision taken by the South African government alone (Pretoria News, 25 March 2009). Both countries did, however, clearly use public diplomacy such as media statements and public engagements to state their positions on the matter engaging the 


\section{AFRICAN \\ EAST-ASIAN \\ AFFAIRS

public through the media.

Regarding the 2009 visa denial, the Chinese embassy in Pretoria, admitted through the media to using traditional diplomacy in appealing to the South African government not to allow the Dalai Lama into the country (Pretoria News Weekend, 21 March 2009). The Chinese embassy warned that it would harm bilateral relations and explained that it was a particularly inopportune time for the Dalai Lama to be visiting South Africa, referring to the $50^{\text {th }}$ anniversary of the Tibetan uprising (Pretoria News Weekend, 21 March 2009). The Chinese embassy further indicated that for South Africa to allow the Dalai Lama into the country would greatly harm South African-Chinese relations (The Star, 23 March 2009). The Chinese government also expressed appreciation for countries that "rejected" the Dalai Lama, saying all countries should respect China's sovereignty and territorial integrity and "oppose Tibetan independence". Issuing this statement to the media was most probably aimed at influencing the communication environment and through this, the South African government's further handling of the matter.

The South African government was perhaps more reluctant to use the public diplomacy instrument, and was most likely only forced into putting its position on the matter in the public domain by the outcry from media and civil society against its disinclination to issue visas to the Dalai Lama. The South African government was mostly prompted for information on the situation, first insisting that no invitation had been extended to the Dalai Lama; then stating that it had decided it was not in South Africa's interest to invite the Dalai Lama, putting forward the argument that the Dalai Lama would divert the attention from the 2010 FIFA World Cup and the peace conference (iol, 22 March 2009; Pretoria News, 23 March 2009). The South African government eventually added that it was also faced with the choice of either allowing the Dalai Lama access or damaging relations with China, but rejected suggestions that it had denied him entry under pressure from China (The Mercury, 26 March 2009).

The progressive divulgence of the government's stance seems to prove that its hand might have been forced into acceding to handling this on a public diplomacy 
AFFAIRS

platform. It may much rather have used traditional "silent" diplomacy techniques to address the issue, but the civil society and media sentiment on the matter was such that it had to state its case in public.

The same reluctance to divulge information was evident around the 2011 visa dispute. South Africa initially maintained that the Dalai Lama had not applied for a visa in New Delhi (The Mercury, 1 April 2009). In 2011, the government was even more secretive about the process and eventually did not take a decision at all. The only statement on the issue really offered voluntarily was the unfortunate assertion that the visa would have been granted had the Dalai Lama not cancelled his visit (iol, 5 October 2011). It seems a valid observation from both events that government only went public on the matter under duress.

As in 2009, utterances by the Chinese government around the 2014 visa application from the Dalai Lama were to a certain extent more revealing that those of the South African government. China's Foreign Ministry spokesman, Qin Gang, thanked South Africa for its support saying China highly appreciated the respect given by the South African government to China's sovereignty and territorial integrity and the support given to China on this issue (FMPRC, 2014)

Again in 2014, the South African government maintained that it had not denied the Dalai Lama a visa, because he had effectively cancelled his own application by indicating he would not be attending the summit (The Citizen, 4 October 2014). In this instance, local government through Cape Town Mayor Patricia de Lille communicated on the matter accusing the national government of scuppering the summit by denying the Dalai Lama a visa (Cape Argus, 3 February 2014). As with the previous applications, national government only communicated on the matter when there was no other option.

\section{The messenger and the message: media and foreign policy}

Internationally, the media's role and functions in international relations, foreign policy and diplomacy is accepted as the so-called CNN Effect (Robinson, 1999: 301309; Gilboa, 2005: 27-44) or the Al Jazeera Effect (Seib, 2008). The newsworthiness 


\section{AFRICAN \\ EAST-ASIAN \\ AFFAIRS

of Sino-South African relations for the South African media lies in, amongst others, the rapid expansion of these bilateral relations; historical ties; and continued expressions of solidarity in global affairs. It also lays in the contradictions - such as human rights issues - emanating from these relations. Therefore, the South African media often view Beijing and Pretoria's relations in normative terms; supporting the notion that the South African media has a binary ("friend or foe; predator or partner; profit or plunder") view of China (Wasserman, 2012: 341). This binary view was also evident in the media's framing of the Dalai Lama Affair questioning the South African government's national interests. Instead, the media reframed these visa denials as South Africa's bowing to pressure from China and thus contradicting South Africa's human rights foreign policy. Whereas the media heavily criticised the South African government's handling of the Dalai Lama Affair, it was relatively silent on criticising China for pressurising South Africa; China's occupation of Tibet; and its treatment of the Dalai Lama.

Even if opinions expressed through the media do not actually change foreign policy, they do influence the content of public diplomacy messaging. The media and those quoted in the media could not sway the government to change its position on granting a visa to the Dalai Lama, but the government was pushed to review the content of its messages or its approach to the issue as indicated above.

After the 2009 invitation it even seemed as if government may have been convinced to review its visa diplomacy, with an undertaking that the Dalai Lama would be welcomed in future. Still, when faced with the 2011 and 2014 invitations, it was clear that this was not the case. The study also made it clear that the priorities of human rights and national interests cannot always be pursued in concord. This sentiment was expressed by analysts, but the government did not see its way clearly to articulate this angle in public communication.

\section{Conclusion}

Despite a shared historical experience of colonialism; foreign domination; exiled liberation leaders and movements; and human rights advocacy, South Africa has no historical or present diplomatic relations with Tibet; unlike South Africa's relations 

AFFAIRS

with states such as Timor Leste, the Sahrawi Arab Republic, South Sudan and others. The Dalai Lama is an important international figure, and was considered both the spiritual and temporal leader of Tibet until his "political retirement" in 2011 (His Holiness the $14^{\text {th }}$ Dalai Lama of Tibet, Undated). As a Nobel Peace laureate he is also an important diplomatic and ceremonial actor but who's diplomatic status is compromised by his exile and his state's occupation by China, a global superpower and a permanent member of the UNSC.

The South African media reviewed for this research payed considerable attention to the Dalai Lama Affair, while displaying predominantly negative media attitudes towards the South African and Chinese governments. Moreover, the main themes emanating from media reaction was South Africa's inability to withstand Chinese pressure, and that this poorly reflects on our human rights foreign policy. The public diplomacy efforts of the South African government stand in stark contrast to this. Here, media attention was often reactive; negative towards the Dalai Lama, but positive towards China; with the benefits from maintaining and improving SinoSouth African relations in order to enhance South Africa's national interests the major theme. The South African government was also aware of its place branding in respect of, for example, the 2010 FIFA World Cup which, it seemed, turned out to be South Africa's competitive branding vis-a-vis the Dalai Lama.

The Dalai Lama Affair is likely to be repeated in future as South Africa consolidates its relations with China even further. It is hoped that the media will retain its robustness in respect of South Africa's foreign policy. Moreover, the Dalai Lama Affair is also a call to democratise South Africa's foreign policy to reflect public opinion, including that of the media.

\section{Endnotes}

1. In-group preference or bias, is a pattern of conduct favouring members of the own group over those who are not within the group. 


\section{AFRICAN \\ EAST-ASIAN \\ AFFAIRS

2. The Mbeki administration's "quiet diplomacy" in the light of Zimbabwe defaulting on undertakings to uphold the rule of law (Mhango, Undated).

3. Concerns about South African engagements with China in the light of the latter's control over its media and issues of human rights (Anthony et al., 2015).

\section{Bibliography}

Adler, E. 1997. Seizing the middle ground: Constructivism in world politics. European Journal of International Relations, 3(3):24-54.

Alden, C., and Y. Wu. 2014. South Africa and China: The Making of a Partnership. Occasional Paper 199. Johannesburg: South African Institute of International Affairs.

April, F.Y., and G. Shelton (eds.). 2014. Perspectives on South Africa-China relations. Pretoria: Africa Institute of South Africa.

BBC. 2000. "Mbeki silent on China rights". [Online]. Available: http:// news.bbc.co.uk/2/hi/africa/727357.stm [Accessed: 5 October 2016].

Business Day Live. 2016. "SA refuses Dalai Lama visa for Nobel summit, says spokeswoman”. 2 September 2014.

Buthelezi \& another v Minister of Home Affairs \& others (242/12) [2012] ZASCA 174 (29 November 2012).

Cape Argus. 2014. "Ignoble disaster for city”. 3 October 2014.

Cape Times. 2009. "Government 'didn't act under Chinese pressure”. 23 March 2009.

Cape Times. 2011. “In denial”. 5 October 2011.

Cape Times. 2011. “Tutu tells ANC: I'll pray for your downfall”. 5 October 2011. 
AFRICAN

EAST-ASIAN

AFFAIRS

Cape Times. 2011. “What price our principle?”. 6 October 2011.

Cox, R. 1981. Social Forces, States and World Orders: Beyond International Relations Theory. Millennium: Journal of International Studies, 10(2):126-155.

Daily News. 2009. "Nobel exits leave peace event in doubt”. 24 March 2009.

Daily News. 2009. “What price our principle?”. 6 October 2011.

Daily News. 2011. "Don't be intimidated”. 13 October 2011.

DFA (Department of Foreign Affairs). 1993. New pillars for a new world. [Online]. Available: http://www.foreignaffairs.com/articles/49408/nelson-mandela/southafricas-future-foreign-policy [Accessed: 2 July 2013].

DFA. 2005. Fundamental principles and guidelines for South Africa's foreign policy in the strategic foreign policy document. [Online]. Available: http:// www.dfa.gov.za/docs/2005pq/pq1817.htm [Accessed: 12 September 2012].

DFA. 2007. Human rights and SA foreign policy. [Online]. Available at: http:// www.dfa.gov.za/docs/2007pq/pq25.htm [Accessed: 12 September 2012].

Finnemore, M., and K. Sikkink. 1998. International norm dynamics and political change. International Organization, 52(4):887-917.

Fuchs, A., and N. Klann. 2011. Paying a visit: The Dalai Lama Effect on international trade. Discussion Papers, Center for European Governance and Economic Development Research, No. 113. [Online]. Available at: http:// hdl.handle.net/10419/70231 [Accessed: 14 October 2016].

Gilboa, E. 2005. The CNN Effect: The Search for a Communication Theory of International Relations. Political Communication, 22(1):27-44.

Hall, T. 2011. We will not Swallow This Bitter Fruit: Theorizing a Diplomacy of Anger. Security Studies, 20(4):521-555.

Henley \& Partners. 2014. The Henley \& Partners Visa Restrictions Index 2014, p 2. [Online]. Available: http://www.straitstimes.com/sites/straitstimes.com/ 
AFRICAN

EAST-ASIAN

AFFAIRS

files/20140418/VISA_Index_2014_04_11_Web.pdf [Accessed: 9 June 2015]. Independent Media. 2015. "Our brands". [Online]. Available: http:// www.independentmedia.co.za/en/our-brands/newspapers/daily/ [Accessed: 12 June 201].

iol (Independent Online). 1999. "Mbeki under fire over Dalai Lama". [Online]. Available: http://www.iol.co.za/news/politics/mbeki-under-fire-over-dalai-lama -meeting-1.21555 [Accessd: 15 September 2012].

iol (Independent Online). 2009. "Outrage at Dalai Lama's snub". [Online]. Available: http://www.iol.co.za/news/south-africa/outrage-at-dalai-lama-s-snub -1.437927 [Accessed: 10 January 2010].

iol (Independent Online). 2009. "Peace conference postponed". [Online]. Available: http://www.iol.co.za/news/politics/peace-conference-postponed [Accessed: 11 June 2015].

iol (Independent Online). 2011. "Dalai Lama: new SA visa row". [Online]. Available: http://www.iol.co.za/news/dalai-lama-new-sa-visa-row-1.1126319 [Accessed: 11 June 2015].

iol (Independent Online). 2011. "SA must give Dalai Lama a visa". [Online]. Available: http://www.iol.co.za/news/south-africa/western-cape/sa-must-givedalai-lama-a-visa-1.1126912 [Accessed: 10 June 2015].

iol (Independent Online). 2011. "Dalai Lama awaits visa decision”. 2 October 2011. iol (Independent Online). 2011. "This is worse than during apartheid". 5 October 2011.

iol (Independent Online). 2014. "Dalai Lama visa application closed: Dept.". 4 September 2014.

Kariithi, N. 2010. Media analysis models: A GCIS study on appropriate models for use in media analysis of SA government activity. Lecture on media analysis presented at the Government Communication and Information System (GCIS), 
AFRICAN

EAST-ASIAN

AFFAIRS

Pretoria.

Landsberg, C. 2010. The diplomacy of transformation. South African Foreign Policy and Statecraft. Johannesburg: Macmillan.

Mandela, N. 1993. South Africa`s Future Foreign Policy. Foreign Affairs, 72(5):8697.

Mail \& Guardian. 2014. "SA, Rwanda agree to resolve row, says Zuma”. [Online] Available: http://mg.co.za/article/2014-03-26-sa-rwanda-agree-to-resolve-rowsays-zuma [Accessed: 11 June 2015].

Mail \& Guardian. 2011. "Dalai Lama visit to SA hangs in the balance". [Online]. Available: http://mg.co.za/article/2011-09-28-dalai-lama-visit-to-sa-hangs-inthe-balance [Accessed:9 June 2015].

Melissen, J. 2011. Beyond the new public diplomacy. Clingendael Paper No. 3. [Online]. Available: http://www.clingendael.nl/sites/default/ files/20111014_cdsp_paper_jmelissen.pdf [Accessed: 12 June 2015].

Mhango, G.A. Undated. Is Quiet Diplomacy in Consonance with Meaningful Peacemaking in SADC? Lessons from Zimbabwe?" [Online]. Available at: http:// www.saccps.org/french/pdf/1-1/SAPSS\%201(1)\%20Mhango.pdf [Accessed: 5 October 2016].

Ministry of Foreign Affairs of the People's Republic of China. 2014. Foreign Ministry Spokesperson Qin Gang's Regular Press Conference on September 5, 2014. [Online]. Available at: http://www.fmprc.gov.cn/mfa_eng/ xwfw_665399/s2510_665401/t1188665.shtml [Accessed: 5 October 2016].

News 24. 2014. "Govt: Dalai Lama visa application being processed". 4 September 2014.

Nye, J.S. 2010. The new public diplomacy. [Online]. Available: http://www.projectsyndicate.org/commentary/the-new-public-diplomacy [Accessed: 12 June 2015]. 


\section{AFRICAN \\ EAST-ASIAN \\ AFFAIRS

Office of His Holiness The Dalai Lama. Undated. Brief biography. [Online]. Available: http://www.dalailama.com/biography/a-brief-biography [Accessed: 5 October 2016].

Pretoria News. 2009. "Setback for peace event after SA shuns Dalai Lama". 23 March 2009.

Pretoria News. 2009. "Dismay over SA ban on the Dalai Lama". 24 March 2009.

Pretoria News. 2009. "China is the reason SA denied visa". 30 March 2009.

Pretoria News. 2011. "Dalai Lama: our conscience can’t be on sale". 30 August 2011.

Pretoria News. 2011. "Denial of visa was contrary to the spirit of Ubuntu". 6 October 2011.

Pretoria News Weekend. 2009. "SA likely to close borders to Dalai Lama". 21 March 2009.

Pretoria News Weekend. 2009. "Dismay over SA ban on the Dalai Lama". 24 March 2009.

Pretoria News Weekend. 2009. "Peace conference off over SA stand on Dalai Lama”. 25 March 2009.

Pretoria News Weekend. 2009. "China is the reason SA denied visa". 30 March 2009.

Pretoria News Weekend. 2011. "SA still weighting visa application by Dalai Lama". 14 September 2011.

Pretoria News Weekend. 2011. "Denial of visa was contrary to the spirit of Ubuntu". 6 October 2011.

Pretoria News Weekend. 2014. "Come clean on Dalai Lama - DA”. 6 October 2014.

Pretoria News Weekend. 2014. "Shed light in Dalai Lama visa sham". 6 October 2014. 
AFRICAN

EAST-ASIAN

AFFAIRS

Robinson, P. 1999. The CNN effect: can the news media drive foreign policy? Review of International Studies, 25:301-309.

Ross, A. et. al. 2015. South Africa's changing foreign policy in a multi-polar world:

The influence of China and other emerging powers. [Online]. Available at: http:// www.ccs.org.za/wp-content/uploads/2015/10/AustriaEmbassy_Report_Final.pdf. [Accessed: 5 October 2016].

SABC (South African Broadcasting Corporation). 2014. "Dalai Lama visa uproar is factually incorrect: DIRCO”. 3 October 2014.

SAIIA (South African Institute of International Affairs). 2009. Fifteen year review of South Africa's role in promoting South-South Cooperation. [Online]. Available: http://www.thepresidency.gov.za/docs/reports/15year_review/irps/ south-south_relations.pdf_[Accessed: 14 March 2012].

Saks, D. 2011. Mandela and the Dalai Lama. [Online]. Available: http:// www.thoughtleader.co.za/davidsaks/2011/10/05/mandela-and-the-dalai-lama/ [Accessed: 14 September 2012].

Seib, P. 2008. The Al Jazeera Effect: How the new global media are reshaping world politics. Dulles: Potomac Books.

Sowetan Live. 2009. "Dalai Lama: Hogan may face hearing”. 26 March 2009. [Online]. Available: http://www.sowetanlive.co.za/sowetan/ archive/2009/03/26/dalai-lama-hogan-may-face-hearing [Accessed: 12 June 2015].

Stringer, K. 2004. The visa dimension of diplomacy. Diplomacy and Statecraft, 15 (4):655-682.

Sunday Independent. 2009. "A peace conference that is closed off to a pacifist". 29 March 2009.

Taylor, D.M. and Doria, J, R. 1981. Self-serving and group-serving bias in attribution. Journal of Social Psychology. 113,(2): 201-211. 


\section{AFRICAN \\ EAST-ASIAN \\ AFFAIRS

Tenzin. Undated. A brief biography of the Dalai Lama. [Online]. Available: http:// hhdl.dharmakara.net/hhdlbiography.html [Accessed: 14 September 2012].

The Citizen. 2014. "Mac blasts De Lille over Dalai Lama comments". 4 October 2014.

The Herald. 2014. "Tutu lashes out over Dalai Lama”. 2 October 2014.

The Independent. 2009. "South Africa bars Dalai Lama from peace conference". 23 March 2009.

The Mercury. 2009. "Why Dalai Lama was denied a visa”. 24 March 2009.

The Mercury. 2009. "Hogan in trouble over Dalai Lama”. 26 March 2009.

The Mercury. 2009. "Dalai Lama thanks China for visa publicity”. 1 April 2009.

The Mercury. 2009. "Should values or interests prevail in our foreign policy?". 29 March 2010.

The Star. 2009. "Tutu, De Klerk threaten boycott after Dalai Lama barred". 23 March 2009.

The Star. 2009. "We want the focus to be on 2010, not Dalai Lama". 24 March 2009.

The Star. 2009. "Foreign policy won't change - and Dalai Lama is welcome". 15 May 2009.

The Star. 2009. "Dalai Lama cancels Tutu trip". 4 October 2011.

The Star. 2009. “Tutu tells ANC: I'll pray for your downfall”. 5 October 2011.

The Star. 2009. "SA a beast that needs to be saved from itself". 6 October 2011.

The Star. 2009. "Denying Dalai Lama a visa could give his peace efforts a boost". 7 October 2011.

The Star. 2009. "Realpolitik - SA style". 3 October 2014.

The Witness. 2014.“Choosing the pragmatic approach”. 3 October 2014. 
AFFAIRS

Tibet Society. 2013. About Tibet. [Online]. Available: http://www.tibetsociety.com/ content/blogsection/6/31/ [Accessed: 20 August 2013].

Titus, D. 2009. Human Rights in Foreign Policy and Practice: The South African Case Considered. Occasional Paper 52. Johannesburg: South African Institute of International Affairs.

Wasserman, H. 2012. China in South Africa: media responses to a developing relationship. Chinese Journal of Communication, 5(3):336-354.

Weekend Argus. 2009. "Disgrace on the world stage. 22 March 2009.

Weekend Argus. 2009 "Tutu, De Klerk threaten boycott after Dalai Lama barred". 23 March 2009. 